\title{
SEASONAL VARIATIONS OF CERTAIN MAJOR ZOOPLANKTON GROUPS AROUND PANGGANG ISLAND, NORTH-WEST OFF JAKARTA
}

\author{
By \\ O.H. ARINARDI ${ }^{1)}$ \\ (Manuscript received 9 August 1977)
}

\begin{abstract}
Seasonal and annual variations of the composition of zooplankton in the water around Panggang Island were studied from May 1971 to April 1973. Temperature and salinity of the water and the abundance of zooplankton were assumed to be affected by the monsoon. It was usually found that the abundance of zooplankton in this area coincided with or occurred after the heavy rainfall. The occurrence of many zooplankton groups in each season did not greatly change, but the intensity of total number were vary in certain groups. The pattern of the annual variation of the zooplankton number was nearly regular in the two years of investigations. The major groups of zooplankton observed during this investigations were also discussed.

In general the zooplankton of the water of Panggang Island were typically neritic. Some bigger species of copepods were even less than in the Java Sea.
\end{abstract}

\section{IKHTISAR}

Variasi musiman dan tahunan komposisi zooplankton di perairan Pulau Panggang diamati dari bulan Mei 1971 sampai dengan April 1973. Suhu dan salinitas serta banyaknya zooplankton diduga sangat dipengaruhi oleh musim. Pada umumnya banyaknya zooplankton di perairan ini dijumpai bertepatan dengan atau sesudah turun hujan lebat. Terdapatnya beberapa golongan zooplankton setiap musimnya tidak mengalami perubahan besar, namun intensitas jumlahnya berbeda pada golongan zooplankton tertentu. Pola variasi tahunan jumlah individu zooplankton hampir teratur selama dua tahun pengamatan. Golongan besar zooplankton yang terlihat selama pengamatan telah pula dipaparkan.

Pada umumnya zooplankton di perairan Pulau Panggang bersifat neritik. Beberapa jenis Copepoda besar bahkan lebih sedikit bila dibandingkan dengan yang terdapat di Laut Jawa.

\section{INTRODUCTION}

The data of plankton and hydrology are the invaluable information for fisheries and these data have been used for catching fish in the developed countries. In the past, however, plankton communities of Seribu Islands water were neglected. In order to catch fish, the fishermen in Jakarta and Seribu Islands usually fished to a place where generally had many fish and when the sea was calm. They did not have any know-

1 Lembaga Oseanologi Nasional — LIPI, Jakarta. 


\section{O. H. ARINARDI}

ledge of plankton migration and plankton seasonal variations. Therefore, it is necessary to make a comprehensive study on plankton in Seribu Islands water in order to discover another fishing ground.

The plankton of the Java Sea, which might have some influences on the water of Seribu Islands, has not been studied properly. Some papers, based mainly on short-termed cruises, have been written by various workers such as CLEVE (1901), ALLEN and CUPP (1935), DELSMAN (1939 \& 1949), PRASENO and TJEE (1966), PRASENO and ARINARDI (1974), and NONTJI and ARINARDI (1975). Primary productivity has been studied by DOTY et al (1963), and SOEGIARTO and NONTJI (1966). The investigations of the hydrological conditions of the Java Sea have been studied, among others, by BERLAGE (1927), SOERIAATMADJA (1956), SJARIF (1959), WYRTKI (1956 \& 1961), and RAHARDJO and ILAHUDE (1965).

This study is aimed at getting comprehensive picture of the seasonal and annual variations of the zooplankton composition of the water around Panggang Island, one of the islands of Seribu Islands group, north-west off Jakarta. It is a hope that this paper will make a basis for a more comprehensive survey, qualitatively as well as quantitatively.

\section{MATERIALS AND METHODS}

\section{General Hydrological Conditions}

Seribu Islands are a group of islands which are distributed from north to south at the north-west off Jakarta. The water which surrounds the islands is known as the water of Seribu Islands. The depth of the water ranges from 10 to $90 \mathrm{~m}$ with the average of $30 \mathrm{~m}$. The water of Seribu Islands is connected with the Java Sea and the mean monthly surface temperature and salinity in this vicinity still followed the characteristics of the Java Sea (KARTORO and BlROWO 1974). The current systems of the Java Sea are influenced by the monsoon. During the west monsoon, which usually prevails from December to February, the mass of water with low salinity (less than 32.0\%) flows eastwardly from the South China Sea. As the result of the run-off of the rivers from Sumatera, Java and Kalimantan, this salinity becomes lower. During the full east monsoon, which prevails from June to August, the mass of water with high salinity (about 34.0\%o) flows westwardly. This mass of water comes from Indian Ocean through Flores Strait, and from pacific Ocean through Sulu Sea and Makassar Strait. Between these two monsoons there are two periods which are usually known as the transition periods, during which the sea temperature is generally high and the sea is calm compared to the situation in the rest of the year (BERLAGE 1927, VEEN 1953, WYRTKI 1956 \& 1961). 


\section{VARIATIONS OF ZOOPLANKTON}

\section{The Location Of The Stations}

The zooplankton hauls were made at nine stations which were located around Panggang Island (Fig. 1). Regular monthly collections between 7 a.m. and 3 p.m. local time at the end of each month were maintained from May 1971 to April 1973. However, in April 1972 and February 1973 the sampling of plankton could not be made due to some difficulties.

Sampling used a Norpac net with mouth diameter of $45 \mathrm{~cm}$ and mesh size of $0.33 \mathrm{~mm}$. At the centre of the mouth net, a TSK flowmeter was mounted. Sampling was done vertically from the depth of $20 \mathrm{~m}$ up to the surface. The samples were preserved in 4\% netural formaline. The displacement volume was done according to the method of WICKSTEAD (1965). The preserved sample was then made up to a known volume (generally $100 \mathrm{ml}$ ) and two fractions (usually 2 x $2.5 \mathrm{ml}$ ) were quickly removed by a stemple pipette into a counting tray and examined under a binocular microscope. The organisms were all counted.

Water temperature and salinity were also studied. The temperature was measured by a reversing thermometer and the salinity of the water was determined according to the method of KNUDSEN.

\section{R E S U L T S METEOROLOGY AND HYDROLOGY}

\section{Rainfall}

In 1971 - 1972 the dry season lasted from July 1971 till September 1971. During this period the rainfall was very low (Fig. 2). The rainy season started in October 1971 and the maximum rainfall was reached in January 1972. During 1972 - 1973 the dry season lasted longer than the previous year, from June to November 1972. This longer dry season seemed having an effect to the hydrological conditions viz. temperature and salinity of the water (Fig. 2).

\section{Temperature}

In $1971-1972$ the minimum temperature $\left(27.50^{\circ} \mathrm{C}\right)$ was observed in January 1972 and the maximum $\left(29.80^{\circ} \mathrm{C}\right)$ in October 1971 (Appendix I). The mean value was $28.63^{\circ} \mathrm{C}$. During $1972-1973$ the temperature was recorded between $28.23^{\circ} \mathrm{C}$ and $30.08^{\circ} \mathrm{C}$ (Appendix II). The mean temperature in this period was $29.06^{\circ} \mathrm{C}$. 


\section{O.H. ARINARDI}

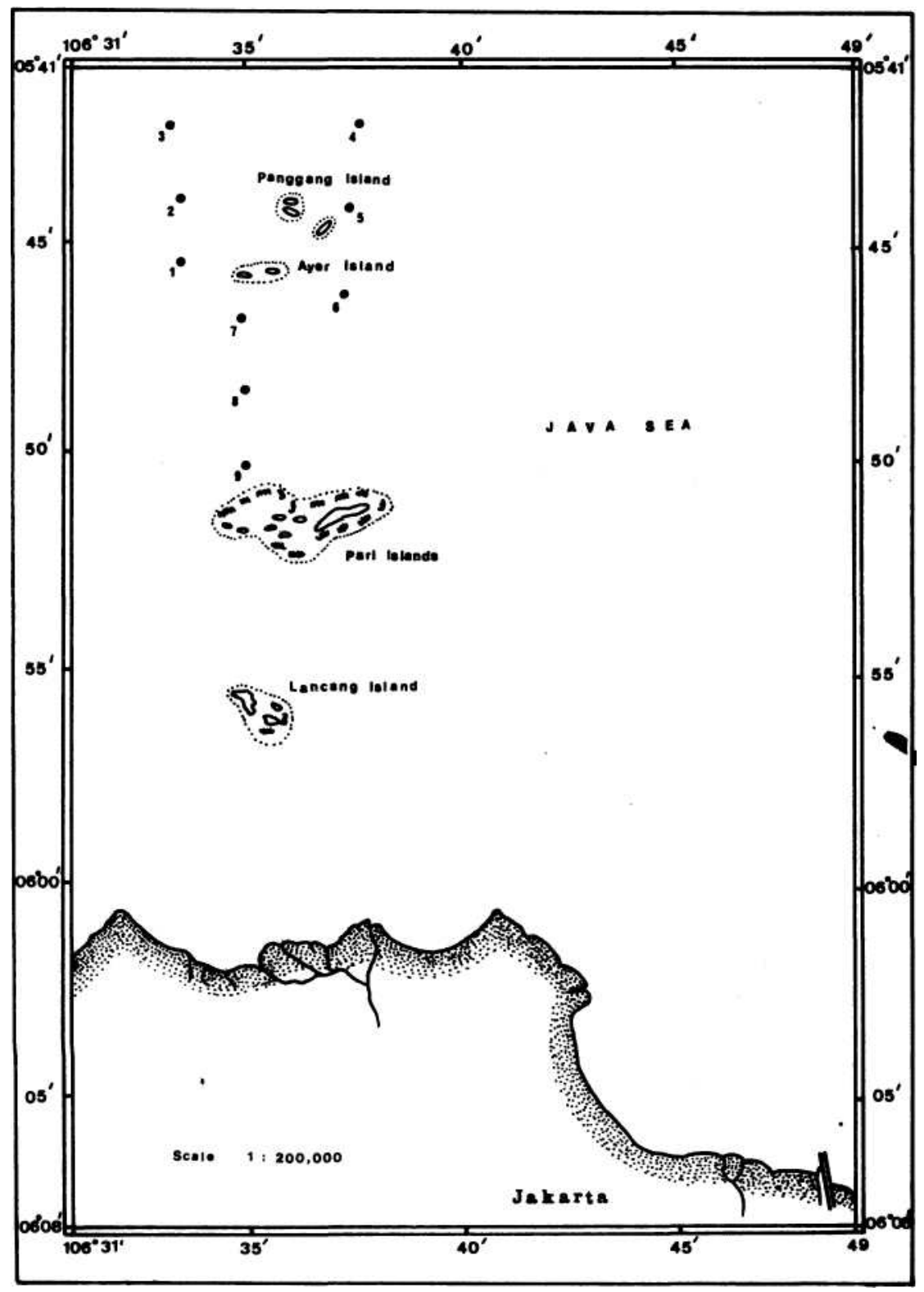

Figure 1. The station positions in the water around Panggang Island where collections and observations were made in 1971 - 1972 and in 1972 - 1973. 


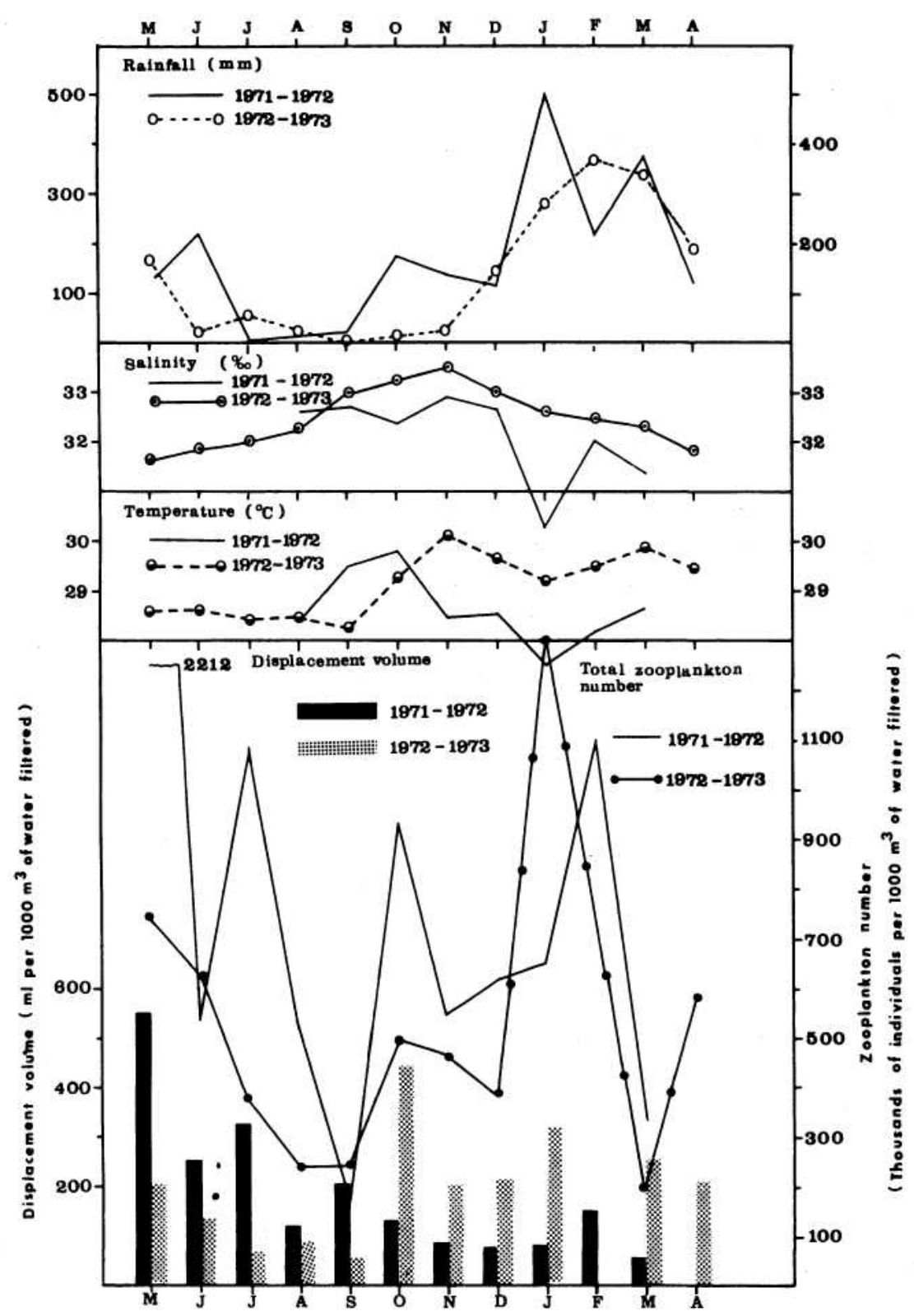

Figure 2. Variations of rainfall, surface salinity, surface temperature, displacement volume and zooplankton number in the water around Panggang Island during the observation periods. 
Salinity

In 1971 - 1972 the minimum salinity (30.29\%) was also recorded in January 1972, coincided with the heavy rainfall. The maximum salinity (32.90\%) was found in November 1971 (Appendix I). The mean salinity during this period was 32.11\%o. In 1972 - 1973 the salinity varied between $31.61 \%$ and $33.50 \%$ (Appendix II) with the mean value 32.48\%.

\section{ZOOPLANKTON}

(Fig. 3 and Fig. 4)

\section{Protozoa}

Only the common Protozoa were counted. The most common protozoan, almost present throughout the year, was radiolarian (Ancathometra sp. ?). It reached maximum number in May 1972. Other protozoan was Noctiluca sp., abundant in January 1972.

\section{Coelenterata}

Hydroida

Anthomedusae, Leptomedusae, and Trachymedusae were present throughout the year. At times the number quite plentiful, for instance in November, December 1971 and October 1972.

\section{Siphonophora}

During 1971 the siphonophores occurred in abundance in October and in November 1971. In 1972 they were found in abundance from May to October 1972. The most common genera encountered were Diphyes and Lensia.

\section{Chaetognatha}

Chaetognaths were found in great number throughout the periods of investigations, except in September 1971. The most common genus was Sagitta.

\section{Annelida}

Tomopteris sp. occurred occasionally and only in rare number. Other polychaet larvae were present almost throughout the year but rarely in large number. 


\title{
VARIATIONS OF ZOOPLANKTON
}

\author{
Crustacea
}

\section{Cladocera}

This group was very rare. The only genera recorded were Evadne and Penilia. The former was found more numerous than the latter.

\section{Ostracoda}

This group was rather common. During 1971 - 1972 they were found abundantly in period between June and August 1971. In 1972 1973 the abundance was recorded in July, August, September 1972 and January 1973. For the rest of the months they appeared in small number or absent. The common genera were Euconchoecia and Pyrocypris.

\section{Copepoda}

The copepods formed the major component of the zooplankton community (varied between $15.92 \%$ and $66.38 \%$ ) almost throughout the year, except in September 1971, March, August 1972 and March 1973. The calanoids were more predominant than the other groups of copepods.

It seemed that the abundance of calanoids appeared after or coincided with the rainfall. The most common genera were Acrocalanus, Paracalanus, Eucalanus, Centropages, Temora and Acartia.

The cyclopoids usually had less number than the calanoids did, but in March 1973 the record showed more cyclopoids than calanoids. The common genera of the cyclopoids were Oithona and Corycaeus, some species of Oncaea were recorded and Sapphirina and Copilia were rarely caught.

The harpacticoids were never found in abundance throughout both years of observations, except in July and October 1971. The common genera that could be encountered were Euterpina and Macrosetella. Microsetella and Clytemnestra were rarely observed.

\section{Cirripedia larvae}

This group was never found in great number.

\section{Mysidacea and Euphausiacea}

These two groups of zooplankton were very rare.

\section{Amphipoda}

Amphipods were never observed in abundance. The common genus was Hyperia. 


\section{O. H. ARINARDI}

\section{Decapoda larvae}

Included to this group were the larvae of Macrura, Brachyra and Anomura. They were found in fair number particularly during 1972 1973. Lucifer sp. was almost found throughout both years of investigations but rarely in great number. The higher number of decapod larvae were observed in July 1971, May, June 1972 and January 1973.

\section{Mollusca}

Molluscs were found throughout the years of investigations. There were three periods in which the molluscs were in high count, that was in August, November 1971 and September 1972. The common genus of molluscs was Creseis.

\section{Echinodermata}

In 1971 - 1972 the larvae of echinoderm were very abundant in May 1971 and March 1972. During 1972 - 1973 there were three peaks; in May, November 1972 and April 1973. The most common echinoderm larvae were ophiuroid larvae and echinoid larvae.

Tunicata

\section{Larvacea}

This group could be found throughout both years of investigations though rarely in high quantity. In $1971-1972$ the higher number were observed in July 1971 and February 1972. During 1972 - 1973 the peaks were found in October 1972 and January 1973. The most common genus of tunicates was Oikopleura, Fritillaria rarely observed.

\section{Thaliacea}

Thaliaceans were usually more abundant in dry season. During 1971 - 1972 the prominent number were recorded in May, July and September 1971. In 1972 - 1973 the abundance of thaliaceans was found in October, November and December 1972. The common genera of this group were Thalia and Doliolum. The latter were less than the former.

\section{Vertebrata}

Fish eggs and fish larvae were not very abundant in the area of investigations throughout both years of observations, but they were rarely absent. 


\section{VARIATIONS OF ZOOPLANKTON}

DISPLACEMENT VOLUME AND TOTAL NUMBER

(Appendix III and Appendix IV)

During 1971 - 1972 the displacement volume of zooplankton was found extremely high in May $1971\left(554 \mathrm{ml} / 1,000 \mathrm{~m}^{3}\right)$ due to the outburst of the echinoderm larvae. The second and third peaks happened in July and September 1971, then the volume decreased gradually and reached the minimum in December $1971\left(80 \mathrm{ml} / 1,000 \mathrm{~m}^{3}\right)$, till it reincreased in February $1972\left(155 \mathrm{ml} / 1,000 \mathrm{~m}^{3}\right)$. This was after the maximum rainfall in January 1972. The lowest value was found in March 1972 (62 ml/ $1,000 \mathrm{~m}^{3}$ ). The mean displacement volume was $189 \mathrm{ml} / 1,000 \mathrm{~m}^{3}$. The peaks of the total zooplankton number were observed in May, July, October 1971 and February 1972 (2,212; 1,081; 933; 1,099 individuals $/ 1,000 \mathrm{~m}^{3}$ respectively). The mean total number was 793,638 individuals $/ 1,000 \mathrm{~m}^{3}$

In 1972 - 1973 rather high displacement volume was found in May $1972\left(211 \mathrm{ml} / 1,000 \mathrm{~m}^{3}\right)$, which coincided with the peak of the rainfall. The second peak was observed in October $1972\left(449 \mathrm{ml} / 1,000 \mathrm{~m}^{3}\right)$. The third peak of volume was recorded in. January 1973 (326 ml/1,000 $\mathrm{m}^{3}$ ). This was also coincident with the rising of the rainfall. The mean displacement volume was $205 \mathrm{ml} / 1,000 \mathrm{~m}^{3}$. The zooplankton showed the same pattern with the fluctuations of the displacement volume. The first peak was found in May 1972 (740 individuals $/ 1,000 \mathrm{~m}^{3}$ ), and gradually decreased till it reached the minimum in August 1972 (238 individuals $/ 1,000 \mathrm{~m}^{3}$ ). The second peak was observed in October 1972 (494 individuals $/ 1,000 \mathrm{~m}^{3}$ ) and the third peak was recorded in January $1973\left(1,301\right.$ individuals $\left./ 1,000 \mathrm{~m}^{3}\right)$. The mean total number was 511,328 individuals $/ 1,000 \mathrm{~m}^{3}$.

\section{SEASONAL AND ANNUAL VARIATIONS}

Studies on the seasonal variations of the zooplankton composition of the various planktonic groups showed that there was a slight change in the zooplankton community (Figs. 3 -5). During 1971 - 1972, after the rainy season in May 1971, there was a blooming of echinoderm larvae. In this period, the other important groups of animals that were encountered were chaetognaths, calanoids, cyclopoids, larvaceans and thaliaceans. This composition still remained till June 1971. In July 1971 (the beginning of the dry season) there were extremely high number of ostracods and salpids. At the end of the dry season (September 1971), the number of the zooplankton, however, were exceptionally low. When the rainy season was beginning in October 1971, there was an outburst of calanoids. Other prominent groups of zooplankton were coelenterates, chaetognaths, crustaceans non copepods, cyclopoids and larvaceans. From November 


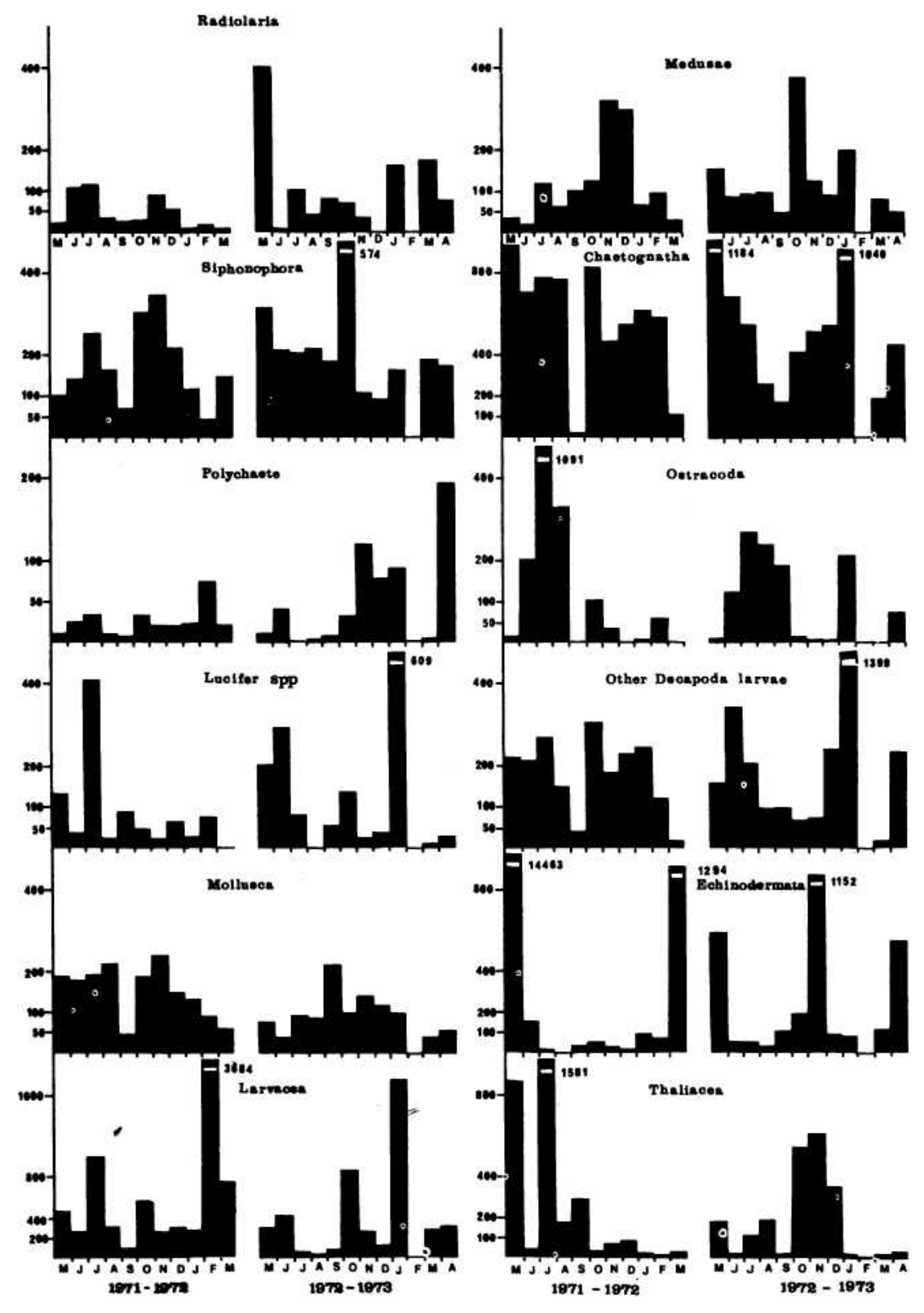

Figure 3. The abundance of zooplankton, expressed as thousands of individuals per $1,000 \mathrm{~m}$ of water filtered, throughout the observation periods. 


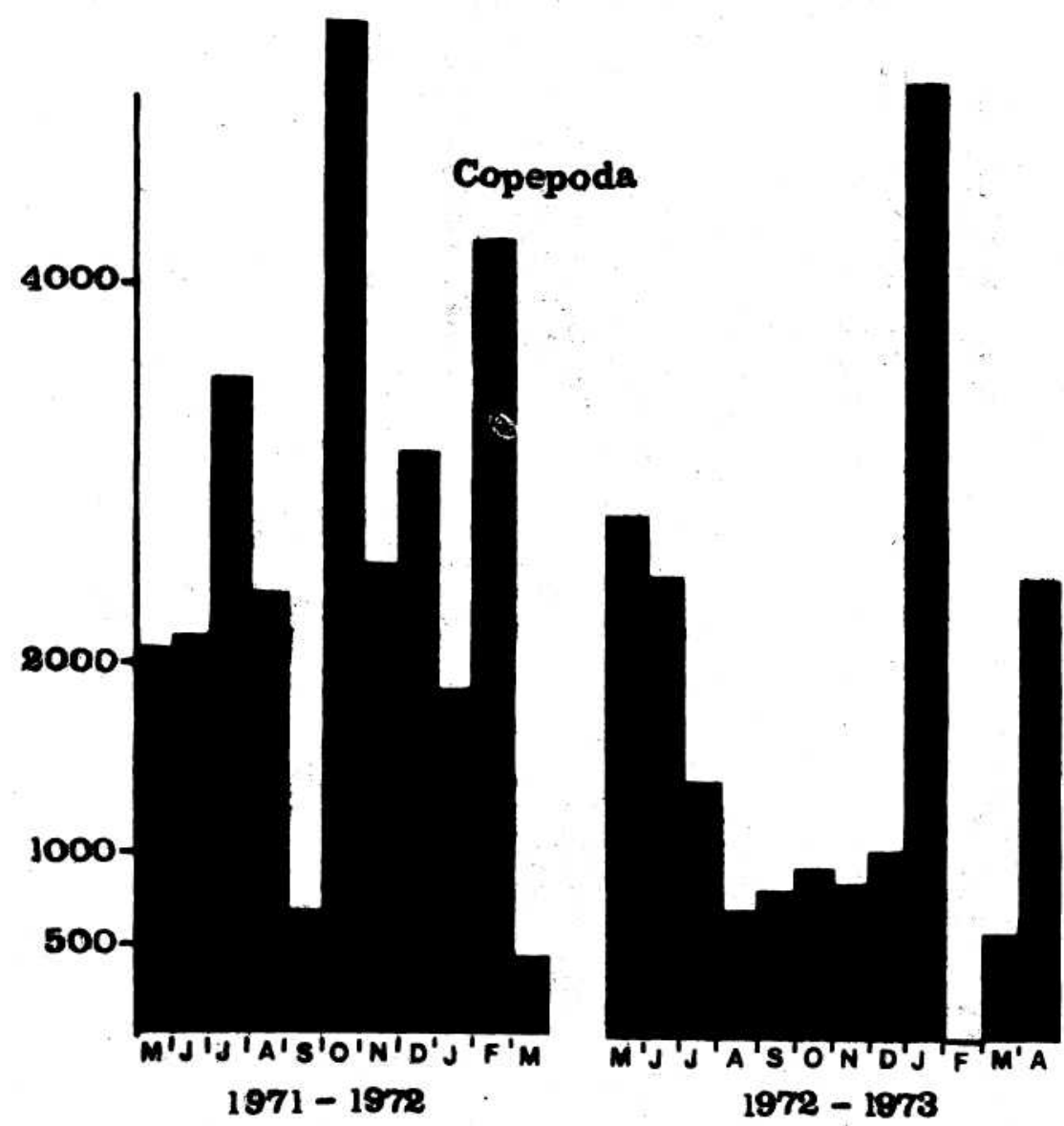

Figure 4. The abundance of Copepoda, expressed as thousands of individuals per $1,000 \mathrm{~m}^{3}$ of water filtered, throughout the observation periods. 


\section{O. H. ARINARDI}

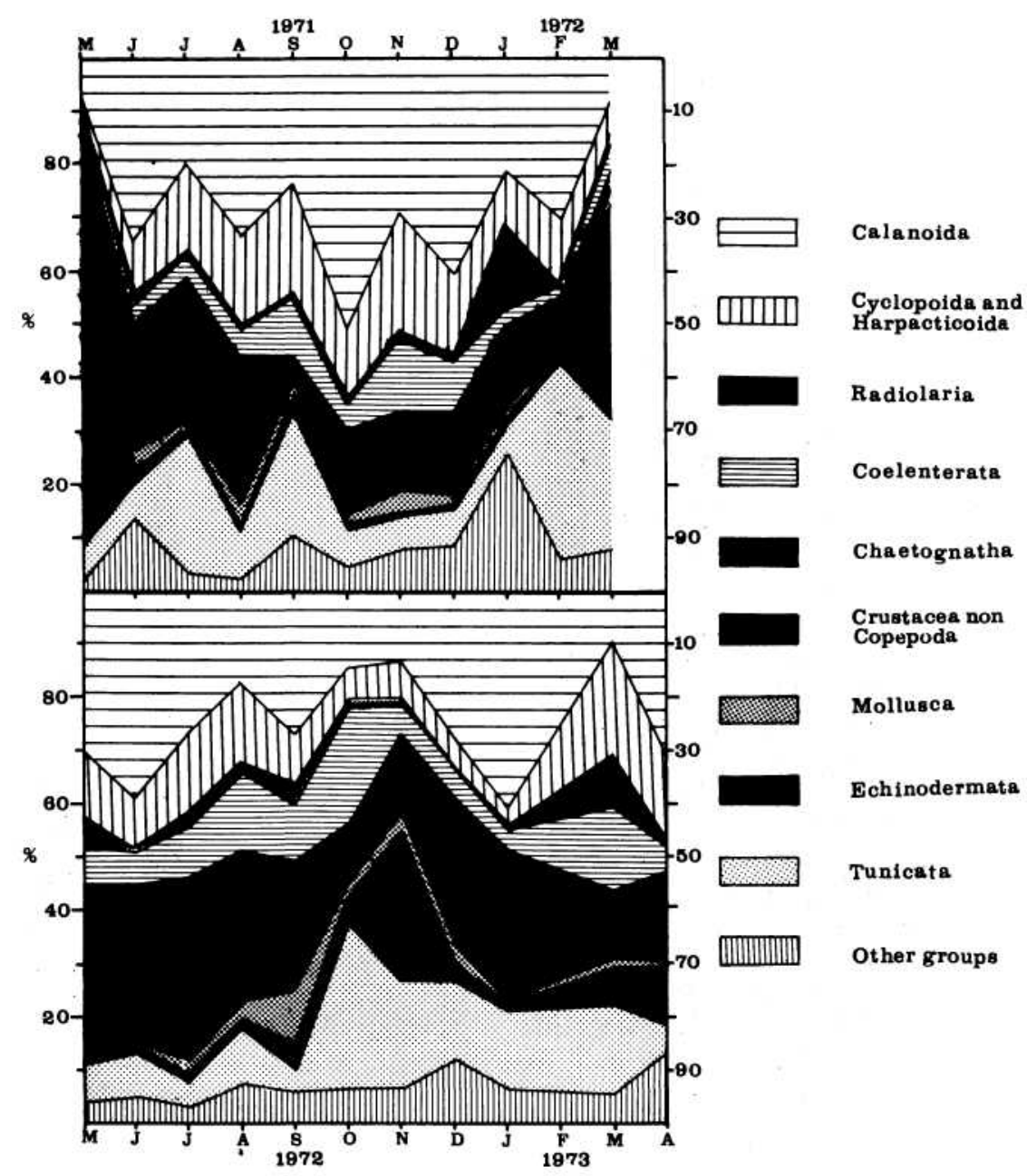

Figure 5. Variations in the relative abundance of major zooplankton groups from May 1971 to March 1972 and from May 1972 to April 1973. 


\section{VARIATIONS OF ZOOPLANKTON}

1971 to January 1972 the composition still unchanged. In February 1972, after the heavy rainfall in January 1972, there was a blooming of Oikopleura sp. In March 1972 the blooming of the echinoderm larvae reappeared.

In 1972 - 1973, at the end of the wet monsoon (May 1972) the zooplankton relatively in high number were coelenterates, calanoids, cyclopoids and echinoderm larvae. In this month chaetognaths were found extremely high when it was compared to the rest of the year. In June 1972 (the beginning of the dry season) chaetognaths, ostracods, calanoids, Lucifer sp. and larvaceans were moderately high. In AugustSeptember 1972 the zooplankton were observed in very low number. At the end of this season, however, siphonophores, medusae, larvaceans and thaliaceans were found extremely high. A blooming of echinoderm larvae was also recorded. After the heavy rainfall in January 1973, all organisms were nearly observed in large number, especially chaetognaths, calanoids, decapod larvae and Oikopleura sp. were encountered in blooming. At near the end of the wet season the echinoderm larvae were found in abundance again.

The pattern of the annual variations in the zooplankton was more or less regular in the two years of investigations (Figs. $2-4$ ). The seasons of occurence of many zooplankton groups did not greatly change, but the intensity of total number varied in certain groups. Ostracods, copepods and tunicates showed higher number of occurrence in the first year, while coelenterates, polychaetes, Lucifer sp. and other decapod larvae were more plentiful in the second year.

During the first year, echinoderm larvae were showing outburst in May 1971 and in March 1972. In the second year the greatest number of echinoderm larvae was recorded in November 1972. The chaetognaths, for both years of investigations, showed quite the same number.

\section{DISCUSSIONS AND CONCLUSIONS}

During the wet season the temperature and salinity values in this vicinity were usually low, especially after the heavy rainfall in January 1972, which dropped to minimum (Fig. 2). In this month the total zooplankton number were relatively low. In February 1972, in accordance with the increasing of the temperature and salinity, the zooplankton were observed in a large number. The changes in the temperature and salinity of the water seemed to play a role to the abundance of zooplankton population, however, as suggested by WICKSTEAD (1958) these parameters were not the real causative factors. Temperature, salinity and the abundance of zooplankton assumed to be affected by a common factor, that was the monsoon. This assumption may be accepted by comparing with the variations of the hydrological para- 


\section{O. H. ARINARDI}

meters and the total amount of zooplankton. The abundance of zooplankton in this area generally coincided with or occurred after the heavy rainfall in the wet monsoon. This was particularly true for the year 1971. The rainy season in 1971 lasted till June 1971. The heavy and continuous rains accompanied by the stormy weather in the sea probably resulting in water mixing of the upper and lower layers. It was worthy to note that a large amount of freshwater which was brought in by the rivers in Java, mainly the Cisadane and the Citarum rivers, influenced the hydrological conditions and hence the nutrient supply of the water around Seribu Islands. This enrichment of the water which was caused by the heavy rainfall and the run-off of the rivers was responsible for the abundance of zooplankton in that vicinity. The effect of the rainfall and the land drainage upon the thriving of the plankton in the Java Sea and the adjacent water has also been mentioned by several authors (DELSMAN 1939, THAM 1953, DOTY et al. 1963, CHUA 1970, PRASENO and ARINARDI 1974, NONTJ and ARINARDI 1975 and HUTOMO 1975).

Comparing the intensity of the rainfall in the two years of investigations, it appeared that in the first year which had a higher and longer rainfall, the number of zooplankton was also higher (793,638 individuals/ $\left.1,000 \mathrm{~m}^{3}\right)$ than the number of zooplankton in the second year $(511,382$ individuals $/ 1,000 \mathrm{~m}^{3}$ ). This was perhaps showing other evidence that supported the statement that the changes of the number of zooplankton were closely associated with the intensity of the rainfall.

The total number of the zooplankton communities were changeable in each season. It was noted that the chaetognaths, calanoids and decapod larvae were extremely in low number in September and March within both years. These two months are usually the beginning of the change-over period from dry to wet season and vice-versa. The calanoids, decapod larvae and larvaceans were recorded in high count mostly coincided with or after the heavy rainfall. Ostracods were more common at the beginning of the dry season whilst thadiaceans were more abundant during the dry season.

Throughout both years of investigations, it seemed that the zooplankton observed were nearly all neritic. This observations resembled to the zooplankton of the Java Sea, which was mentioned by DELSMAN (1949) that the zooplankton in the Java Sea were having coastal characters. From this investigations, it showed that some bigger species of copepods such as Euchaeta sp. and Labidocera sp. were even less in number here than in the Java Sea.

\section{ACKNOWLEDGEMENTS}

I wish to express my thanks to Mr. KASIJAN ROMIMOHTARTO, marine biologist of the National Institute of Oceanology, for his encouragement and criticisms in the preparation of this paper; to Mr. R. KASTORO, oceanographer of the National Institute of Oceanology, for providing the hydro- 


\section{VARIATIONS OF ZOOPLANKTON}

logical data; and also to the Meteorological and Geophysical Institute, Jakarta, for providing meteorological data.

\section{REFERENCES}

Allen, W.E. and E.E. Cupp 1935. Plankton diatoms of the Java Sea. Ann. Jardin Botan. de Buitenzorg 44 (2): $1-174$.

BERLAGE, H.P. 1927. Monsoon currents in the Java Sea and its entrances. Verhand. Kon. Magn. on Meteor. Observat., Butavia. 19: $1-19$.

ChuA , T.E. 1970. A preliminary study on the plankton of the Ponggol Estuary. Hydrobiologic 35 (2): $254-272$.

Cleve, P.T. 1901. Plankton organisms from the Indian Ocean and the Malay Archipelago. Kongl. Sv. Akad. Handl. 35 (5): 1 - 58 .

Delsman, H.C. 1939. Preliminary plankton investigations in the Java Sea. Treubia 17 (2) : $139-181$.

, 1949. Copepods in Sunda Strait. Bijdr. Tot de Dierkunde 28:127-132.

Doty, M.S., Rd. E. SoeriaAtmadja and A. Soegiarto 1963. Observations on the primary marine productivity of northwestern Indonesian waters. Mar. Res. Indon. 5: $1-25$.

Hutomo,M. 1975. Variasi musiman fitoplankton di perairan sekitar Pulau Ayer. Oseanol. di Indon. 4: $1-12$.

Kastoro and S. Birowo 1974. Seasonal changes in sea surface temperature and salinity around Pulau Ayer. Oseanol. di Indon. 3:1 - 10 .

Nontu, A. and O.H. Arinardi 1975. Hidrologi dan diatom plankton di Laut Jawa. Oseanol. di Indon. 4: $21-36$.

Praseno, D.P. and TJEE O.H. 1966. A quantitative study on the zooplankton of the waters around Java. Pac. Sci. Congr. IX Proc. 2: page 45 (Abstract).

-------,1974. Volume plankton dan penyebarannya di perairan Pulau-Pulau Seribu pada Musim-musim Timur dan Barat 1971. Oseanol. di Indon. 2 : 27 - 40.

RAHARDJO, G. and A.G. ILAHUDE 1965. Temperature and salinity observations in the Java Sea. Baruna Exped. J., Sect. ABC (1): $77-116$.

SJARIF, S. 1959. Seasonal fluctuations in the surface salinity along the coast of the southern part of Kalimantan (Borneo). Mar. Res. Indon. 4 : 1- 29.

Soegiarto, A. and A. Nontu 1966. A seasonal study of primary marine productivity in Indonesian waters. Pac. Sci. Congr. IX Proc. 2: page 61 (Abstract).

SoeriaAtmadja, Rd. E. 1956. Seasonal fluctuations in the surface salinity off north coast of Java. Mar. Res. Indon. 1: $1-19$.

THAм, A.K. 1953. A preliminary study of the physical, chemical and biological characteristics of Singapore Straits. Col. Off. Fish. Publ. 1(4): $1-65$.

VeEn, P.C. 1953. Preliminary charts of the mean salinity of the Indonesian Archipelago and adjacent waters. Organiz. for Scient. Res. in Indon., Bull. 17: 1-47.

WiCKSTEAD, J.H. 1958. A survey of the larger zooplankton of Singapore Straits. J. du Con. 23(3): $340-353$.

1965. An introduction to the study of tropical plank ton. Hutch. Trop. Monogr., London : $1-160$.

WrRtKI, K. 195b. Monthly charts of surface salinity in Indonesian and adjacent waters. J. du Con. Intern. Pour L'Explor. de la Mer. 21(3): $268-279$. $2: 1-195$ , 1961. Physical oceanography of the South-east Asian waters. Naga Report 


\section{O. H. ARINARDI}

APPENDIX I.

Rainfall and hydrological data of the water around Panggang Island, 1971 - 1972.

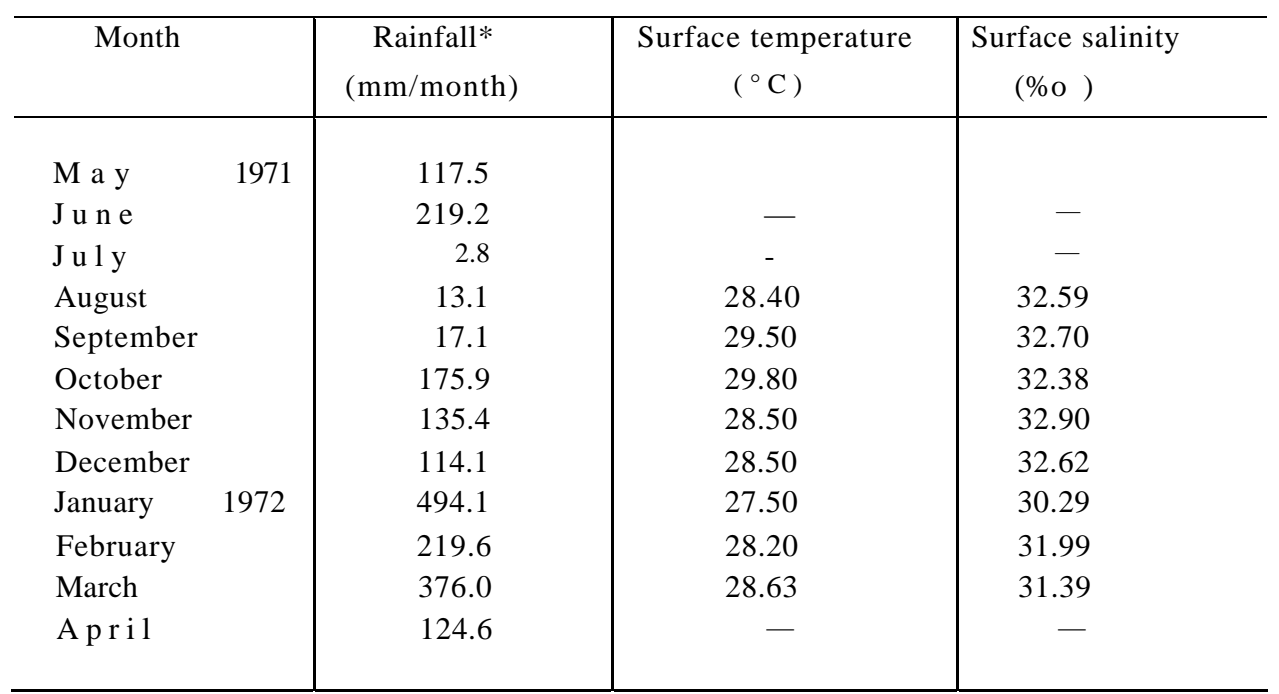

Data from Meteorological and Geophysical Institute, Jakarta.

APPENDIX II.

Rainfall and hydrological data of the water around Panggang Island, 1972 - 1973.

\begin{tabular}{|c|c|c|c|c|}
\hline Month & & $\begin{array}{c}\text { Rainfall* } \\
\text { (mm/month) }\end{array}$ & $\begin{array}{c}\text { Surface temperature } \\
\left({ }^{\circ} \mathrm{C}\right)\end{array}$ & $\begin{array}{l}\text { Surface salinity } \\
\text { (\%«) }\end{array}$ \\
\hline $\mathrm{M}$ a $\mathrm{y}$ & 1972 & 167.6 & 28.57 & 31.61 \\
\hline J u n e & & 22.0 & 28.57 & 31.83 \\
\hline J u l y & & 56.6 & 28.43 & 31.99 \\
\hline August & & 14.2 & 28.43 & 32.50 \\
\hline September & & 0 & 28.23 & 33.02 \\
\hline October & & 17.4 & 29.25 & 33.23 \\
\hline November & & 26.8 & 30.08 & 33.50 \\
\hline December & & 144.7 & 29.65 & 33.00 \\
\hline January & 1973 & 280.0 & 29.21 & 32.59 \\
\hline February & & 369.2 & - & - \\
\hline March & & 345.3 & 29.84 & 32.27 \\
\hline April & & 190.8 & 29.44 & 31.77 \\
\hline
\end{tabular}

* Data from Meteorological and Geophysical Institute, Jakarta. 
APPENDIX III

" Displacement volume $\left(\mathrm{ml} / \mathbf{1 0 0 0} \mathrm{m}^{3}\right)$ and total number of zooplankton (thousands indiv./1OOO $\mathrm{m}^{3}$ ) around Panggang Island water, $1971-1972$.

\begin{tabular}{|c|c|c|c|c|c|c|c|c|c|c|c|c|}
\hline \multirow{2}{*}{ Station } & \multicolumn{2}{|c|}{ May 1971} & \multicolumn{2}{|c|}{ June } & \multicolumn{2}{|c|}{$\mathrm{Ju} \perp \mathrm{y}$} & \multicolumn{2}{|c|}{ August } & \multicolumn{2}{|c|}{ September } & \multicolumn{2}{|c|}{ October } \\
\hline & Volume & Number & \begin{tabular}{|l|} 
Volume \\
\end{tabular} & Number & Volume & Number & Volume & Number & Volume & Number & Volume & Number \\
\hline 1 & 673 & 4128 & 224 & 367 & 84 & 998 & 91 & 766 & 71 & 120 & 172 & 1080 \\
\hline 2 & 475 & 3674 & 118 & 330 & 75 & 747 & 122 & 779 & 89 & 89 & 75 & 1045 \\
\hline 3 & 611 & 2761 & 151 & 976 & 193 & 1044 & 102 & 812 & 128 & 162 & 145 & 1413 \\
\hline 4 & 604 & 2104 & 376 & 976 & 103 & 712 & 51 & 558 & 611 & 236 & 145 & 1072 \\
\hline 5 & 475 & 564 & 401 & 591 & 103 & 890 & 39 & 422 & 106 & 183 & 72 & 790 \\
\hline 6 & 658 & 3200 & 623 & 570 & 196 & 1031 & 180 & 505 & 199 & 127 & 135 & 904 \\
\hline 7 & 319 & 1516 & 294 & 294 & 231 & 632 & 77 & 417 & 225 & 162 & 92 & 541 \\
\hline 8 & 668 & 1177 & 46 & 362 & 117 & 878 & 304 & 208 & 178 & 98 & 156 & 843 \\
\hline 9 & 503 & 788 & 49 & 418 & 1849 & 2795 & 158 & 239 & 271 & 289 & 212 & 713 \\
\hline Tot a l & 4986 & 19912 & 2282 & 4884 & 2951 & 9727 & 1124 & 4706 & 1878 & 1466 & 1204 & 8401 \\
\hline Me a $n$ & 554 & 2212 & 254 & 543 & 328 & 1081 & 125 & 523 & 209 & 163 & 134 & 933 \\
\hline
\end{tabular}


APPENDIX III. (Continued)

Displacement volume $\left(\mathrm{ml} / 1000 \mathrm{~m}^{3}\right)$ and total number of zooplankton (thousands indiv./lOOO $\mathrm{m}^{3}$ ) around Panggang Island water, 1971 — 1972.

\begin{tabular}{|c|c|c|c|c|c|c|c|c|c|c|c|c|}
\hline \multirow{2}{*}{ Station } & \multicolumn{2}{|c|}{ November } & \multicolumn{2}{|c|}{ December } & \multicolumn{2}{|c|}{ January 1972} & \multicolumn{2}{|c|}{ February } & \multicolumn{2}{|c|}{ March } & \multicolumn{2}{|c|}{ April } \\
\hline & Volume & Number & Volume & Number & Volume & Number & Volume & Number & Volume & Number & Volume & Number \\
\hline 1 & 169 & 612 & 84 & 271 & 108 & 672 & 235 & 1458 & 58 & 251 & & \\
\hline 2 & 94 & 724 & 87 & 539 & 78 & 505 & 133 & 1073 & 58 & 473 & & \\
\hline 3 & 135 & 886 & 54 & 831 & 76 & 494 & 179 & 1033 & 63 & 221 & $\pi$ & $\varpi$ \\
\hline 4 & 125 & 225 & 102 & 730 & 56 & 371 & 147 & 1730 & 31 & 279 & $\vec{\sigma}$ & $\vec{\sigma}$ \\
\hline 5 & 49 & 433 & 74 & 819 & 45 & 417 & 183 & 968 & 65 & 239 & a & D \\
\hline 6 & 27 & 262 & 68 & 913 & 50 & 499 & 124 & $58:$ & 77 & 399 & $\therefore$ & $\therefore$ \\
\hline 7 & 101 & 490 & 111 & 590 & 149 & 585 & 155 & 1073 & 134 & 820 & z & z \\
\hline 8 & 37 & 317 & 71 & 325 & 100 & 874 & 90 & 914 & 35 & 140 & & \\
\hline 9 & 68 & 1034 & 68 & 541 & 115 & 1486 & 147 & 1063 & 38 & 307 & & \\
\hline Tot a 1 & 805 & 4983 & 719 & 5559 & 777 & 5903 & 1393 & 9895 & 559 & 3129 & & \\
\hline Me a $n$ & 89 & 554 & 80 & 618 & 86 & 656 & 155 & 1099 & 62 & 348 & & \\
\hline
\end{tabular}




\section{APPENDIX}

Displacement volume ( $\mathrm{ml} / 1000 \mathrm{~m}$ ) and total number of zooplankton (thousands indiv./10 O O m³) around Panggang Island water, $1972-1973$.

\begin{tabular}{|c|c|c|c|c|c|c|c|c|c|c|c|c|}
\hline \multirow{2}{*}{ Station } & \multicolumn{2}{|c|}{ M a 1972} & \multicolumn{2}{|c|}{ June } & \multicolumn{2}{|c|}{$\mathrm{Ju} / \mathrm{y}$} & \multicolumn{2}{|c|}{ August } & \multicolumn{2}{|c|}{ September } & \multicolumn{2}{|c|}{ October } \\
\hline & Volume & Number & Volume & Number & Volume & Number & Volume & Number & Volume & Number & Volume & Number \\
\hline 1 & 216 & 533 & 103 & 670 & 63 & 125 & 104 & 338 & 97 & 368 & 370 & 471 \\
\hline 2 & 231 & 727 & 235 & 806 & 134 & 376 & 172 & 450 & 42 & 306 & 868 & 329 \\
\hline 3 & 231 & 579 & 186 & 558 & 86 & 315 & 73 & 196 & 32 & 329 & 67 & $45 \pi$ \\
\hline 4 & 165 & 939 & 144 & 749 & +6 & 267 & 54 & 82 & 65 & 226 & 638 & 517 \\
\hline 5 & 202 & 800 & 126 & 776 & 175 & 582 & 42 & 153 & 62 & 167 & 336 & 343 \\
\hline 6 & 226 & 671 & 144 & 490 & 56 & 334 & 173 & 250 & 81 & 187 & 477 & 740 \\
\hline 7 & 254 & 953 & 35 & - & 27 & 398 & 92 & 125 & 34 & 202 & 384 & 883 \\
\hline 8 & 203 & 928 & 81 & 431 & 58 & 622 & 81 & 363 & 52 & 112 & 677 & 285 \\
\hline 9 & 174 & 528 & 175 & 526 & 31 & 285 & 58 & 188 & 77 & 253 & 220 & 418 \\
\hline Total & 1902 & 6658 & 1229 & 5006 & 676 & 3304 & 849 & 2145 & 542 & 2150 & 4037 & 4443 \\
\hline Mean & 211 & 740 & 137 & 626 & 75 & 367 & 94 & 238 & 60 & 239 & 449 & 49.1 \\
\hline
\end{tabular}




\section{APPENDIX IV. (Continued)}

Displacement volume $\left(\mathrm{ml} / 1000 \mathrm{~m}^{3}\right)$ and total number of zooplankton (thousands indiv. $1000 \mathrm{~m}^{3}$ around Panggang Island water. $1972-1973$

\begin{tabular}{|c|c|c|c|c|c|c|c|c|c|c|c|c|}
\hline \multirow{2}{*}{ Station } & \multicolumn{2}{|c|}{ November } & \multicolumn{2}{|c|}{ December } & \multicolumn{2}{|c|}{ January 1973} & \multicolumn{2}{|c|}{ Folsuary } & \multicolumn{2}{|c|}{$\mathrm{MI}: \mathrm{t}: \mathrm{h}$} & \multicolumn{2}{|c|}{ An;i! } \\
\hline & \begin{tabular}{|l} 
Volume \\
\end{tabular} & Number & Volume & Number & Volume & Number & Volume & Number & Volume & Number & Volume & Number \\
\hline 1 & 202 & 531 & 248 & 397 & $14 \pi$ & 1680 & & & $16 i 1$ & 191 & 183 & (i) $2:=$ \\
\hline 2 & 134 & 370 & 235 & 403 & 322 & 1107 & & & 270 & 191 & $\ddot{2} \ddot{3}$ & ริ45) \\
\hline 3 & 108 & 382 & 210 & 100 & $46 \overline{5}$ & 1793 & $=$ & $\pi$ & 1173 & 223 & $17 i$ & 452 \\
\hline 4 & 77 & 353 & $2+x$ & 403 & 134 & 1272 & $\bar{z}$ & $\overline{7}$ & 97 & $1: 1$ & 131 & $60 \%$ \\
\hline 5 & 257 & 616 & 214 & 397 & 323 & 1032 & $\infty$ & a & 119 & 114 & $1 \times 6$ & $9+46$ \\
\hline 6 & 134 & 363 & 259 & - & 232 & 1260 & $=$ & $\approx$ & 101 & $26 i 2$ & 349 & 599 \\
\hline 7 & 293 & 440 & 167 & 311 & 365 & 8.5 .5 & z & 7. & T0 & 175 & 336 & 662 \\
\hline 8 & 367 & 308 & 186 & 279 & 293 & 1232 & & & 98 & 1.33 & 220 & 326 \\
\hline 9 & 331 & 815 & 226 & 178 & 132 & 1176 & & & 1.83 & 292 & 147 & 392 \\
\hline Total & 1903 & 4178 & 1993 & 3067 & 2933 & $\lfloor 1707$ & & & 2311 & $175 x$ & 1932 & 5203 \\
\hline M e a $n$ & 211 & 464 & 221 & 383 & 326 & 1301 & & & 257 & 19.5 & 21.5 & ה7t \\
\hline
\end{tabular}

